[Starkey, L., \& Stevens, K. (2007). Three Stages in the Digital Integration of New Zealand Schools. New Zealand Annual Review of Education, 16, 105-117]

\section{Three Stages in the Digital Integration of New Zealand Schools ${ }^{1}$}

\section{LOUISE STARKEY AND KEN STEVENS}

\section{Abstract:}

In New Zealand, teachers and students have been collaborating through digital connections since the early 1990s. Digital integration began as a structural collaboration between rural schools to share staff and resources, developing in a second stage to include regional intranets. In 2007 it is possible to collaborate with the global educational environment from within a classroom or office. A third stage of digital integration in schools is emerging as a result of students and teachers being connected to the internet through broadband, using web 2.0 applications to construct knowledge collaboratively beyond the classroom walls. This paper outlines the three stages and examines their implications for teacher education.

\section{Structural and Personal Digital Integration}

Isolation has always been a feature of education in New Zealand, arguably one of the most remote countries in the world, within which many people have been educated in small schools in rural communities. It could be further argued that New Zealand's isolation has provided an impetus for the acceptance of the internet and its associated technologies and facilitated the development of e-learning. At the structural level, digital, internet-based learning environments have developed to complement traditional education. At the personal or individual level, an expanding range of internet-based technologies provide access to a growing range of educational opportunities. The integration of digital changes in the New Zealand education system at both structural and personal levels has implications for pre-service teacher education programmes.

\section{New Digital Educational Structures}

Three stages can be identified in the development of virtual classes in New Zealand (Stevens, 2003): their origins in small schools in rural communities; an emphasis on collaborative teaching and learning within an otherwise competitive school system; and the co-existence of traditional print-based educational institutions with e-learning based on information and communication technologies. Direct government involvement in e-learning from 1998 with a range of initiatives has encouraged on-line learning and complemented existing educational structures and processes.

Over the last two decades several new educational structures have been created in rural New Zealand based on opportunities provided by the convergence of information and communication technologies. During the 1990s it became possible to link schools electronically within defined areas of the country to form regional intranets (Stevens \& Moffatt, 2003).

Telecommunications technologies have provided ways of sustaining rural educational infrastructures in several regions of New Zealand by enabling teachers and students to electronically link with one another to share resources. The development of e-learning in New Zealand took place when many rural schools were under threat of closure because of their small enrolments. A feature of telecommunications technologies in rural New Zealand schools has been the realisation by both teachers and administrators of their potential to connect one site with another, thereby challenging educational considerations of institutional size, location and access to human, curriculum and technological resources. In the interests of sustaining on-site education in rural New Zealand communities, on-line education has developed at the regional level, enabling virtual classes to be created.

By linking computers to telephone lines through modems, audio-graphic and video-conferencing teaching and learning was initiated in several parts of the country. In the Canterbury region of the South Island and the north east coast of the North Island, small rural schools formed virtual classes to teach senior students collaboratively in a range of specialized secondary school subjects (Stevens, 1999). When two or more schools interface electronically to combine teaching and learning, a virtual class is formed. Both teachers and students in a growing number of rural schools in New Zealand now have a video conference presence across multiple sites during the course of a school week. Three stages can be identified in this development in New Zealand. 
Digital integration (i) the development of virtual classes in selected schools

It has often been difficult to attract teachers to vacant positions in schools in the far north-east coast of the North Island and it is not uncommon for advertised vacancies to attract no applicants at all. In this situation it has been impossible to provide students with an on-site teacher for many subjects within each school. Many students in this part of New Zealand have, accordingly, been enrolled with the New Zealand Correspondence School in Wellington for at least one of their high school courses. To counter the disadvantage of having few on-site teachers in high schools in this part of rural New Zealand, a small, three-site electronic network developed during the 1990s to share teaching resources. As well as linking with one another, each site had access to a growing range of extranets (external systems) - to larger urban secondary schools, to polytechnics in other parts of the country and to the New Zealand Correspondence School in Wellington. Senior students in the three small, predominantly Maori communities were provided with access to teachers and other students in each of the other two schools in the East Coast network, as well as to a small range of non-local educational and vocational resources. The East Coast network attracted the attention of educators in the South Island who worked together to develop a new collaborative structure in rural Canterbury.

\section{Digital integration (ii) the development of a regional intranet}

The Canterbury region contains twelve rural communities, each with its own school. With rural-urban migration many communities in Canterbury have become smaller and enrolments in most schools have fallen. In the last two decades some schools have faced closure and parents had to consider the prospect of considerable disruption in the education of their sons and daughters. The development of an inter-school network that became known as "Cantatech" (The Canterbury Area Schools Technology Project) brought twelve rural schools together to consider ways in which teaching and learning resources could be shared. Each school was able to provide its students with teaching in the core subjects on-site: English, mathematics and science, as well as instruction in one or two specialised subjects (e. g., French, Japanese, economics and agriculture). By collaborating in the teaching of specialist subjects between the schools in this part of rural New Zealand, senior students who wished to receive instruction in courses not locally available have been able to access them from a participating site in the Cantatech network. Because of the necessity of finding new solutions to the delivery of education to geographically isolated senior students, each school in the Cantatech network has had to consider the role of information technology in the curriculum. For teachers, students, administrators and people in each of the participating communities, information technology has become a means to enlarge local educational, and indirectly, vocational, opportunities. As with the East Coast initiative, the Cantatech network developed selected extranets to polytechnics and other educational organizations to further extend educational opportunities for rural Canterbury students. The development of the Cantatech network has brought about many changes in the administrative and academic life of each school. Each school in the network has had to academically and administratively interface with each of the other schools and work collaboratively in the interests of a much broader educational community than its originallydesignated local one. E-teaching and e-learning in rural Canterbury challenged the competitive model of schooling in New Zealand and demonstrated the value of a collaborative, integrated virtual organisation for senior students. This collaboration across schools is likely to increase with the introduction of web $2.0^{2}$ applications and an emerging learning theory for the digital era.

\section{Digital integration (iii) collaboration and knowledge building}

The development of collaborative digital educational structures in New Zealand has been accompanied by new teaching and learning processes, supported by the internet and an expanding range of software. The use of software in society is having an impact on "knowledge" and learning:

Half of what is known today was not known 10 years ago. The amount of knowledge in the world has doubled in the past 10 years and is doubling every 18 months according to the American Society of Training and Documentation (ASTD). (Gonzalez, 2004)

The digital era has seen a review of the definition of what counts as knowledge and its implications for education. There has also been a call for new ways of considering both knowledge and the mind. Bereiter (2002) advocates a move away from the idea of the mind as a container, a perspective he conceptualizes as being part of a "two dimensional world of folk theory" to a focus on knowledge-creation through collaboration between learners. Gilbert (2005) proposes that knowledge be considered as a verb rather than a noun, something that is active rather than passive. Collaboration is central to the work of both authors 
who view knowledge as part of a building process. Knowledge-building is an active process based on collaboration made possible by the development of connections within and between schools. This way of thinking is different from the passive view of knowledge being something that is held in the heads of individuals. When knowledgebuilding is considered as a process (or a verb) based on collaboration, a new perspective on education based on the connections between communities of learners can be considered. The digital integration of classes in New Zealand provides a structural dimension of this conceptual shift.

This collaborative, connected way of considering knowledge in the digital era has implications for teaching and learning in New Zealand schools. Teachers find the use of digital technologies most effective in student learning if their teaching is underpinned by a compatible learning theory. George Siemens (2004) developed a theory known as connectivism for learning in the digital era. Connectivism considers how people, organisations and technology work collaboratively to construct knowledge. Siemens describes connectivism as:

the integration of principles explored by chaos, network, and complexity and self-organization theories. Learning is a process that occurs within nebulous environments of shifting core elements - not entirely under the control of the individual. Learning (defined as actionable knowledge) can reside outside of ourselves (within an organization or a database), is focused on connecting specialized information sets, and the connections that enable us tolearn more are more important than our current state of knowing. (Siemens, 2004)

The pedagogy underpinning connectivism builds on constructivist beliefs (Bruner, 1986; Vygotsky, 1987), and places the knowledge development into networks or communities of learners rather than in the minds of individuals. The collaboration involved in this type of learning activity can include connections between a group of students, their teacher, experts and interested parties beyond their classroom and even beyond their country. Together they may construct or develop knowledge that may or may not already exist. In the process of learning and knowledge-building based on collaboration underpinned by connectivism, web 2.0 has an increasingly important role.

\section{The Digital Integration of New Zealand Schools}

The first generation of internet software was the read-write web (web 1.0), where online users could read what other people had written, and if they had the technical knowledge, and bought the software, they could develop their own web space to show information. The second generation of internet software (web 2.0) allows for interaction between individuals, and the formation of online groups. With an internet connection, anyone can share images, stories, ideas and experiences. By 2005 all New Zealand schools had internet access and $93 \%$ of secondary schools, $78 \%$ of primary schools and $83 \%$ of wharekura had broadband access (Johnson, Kazakov \& Švehla, 2005). Open source sites, which are free for anyone to use, are platforms which have allowed people with similar interests to interact and connect without technical expertise, expanding exponentially the potential for collaborative knowledge building.

The digital integration of New Zealand schools is being enabled through the development of web 2.0 and access through broadband connections. This stage in digital integration includes schools networking and collaborating with schools, educators collaborating with educators, and students networking with the world.

\section{Schools networking and collaborating with schools}

It is likely that the regional networks of schools like Cantatech will continue to develop to share resources in the future. Teaching resources are currently being shared through videoconferencing and online learning environments. The virtual learning network ${ }^{3}$ is currently supported by the Ministry of Education, who facilitate a brokerage system connecting teachers with students, both within regional networks and beyond. This means that students may be physically present at one school, but have teachers and classmates from more than one of them.

Local initiatives are being developed within the regional networks. OtagoNet principals recognised the need to offer rural students the opportunity to study for scholarship examinations in their final year of schooling. As a result they have developed a system of identifying potential scholarship students and teachers from the region who can be linked in the online environment to establish learning/study groups with appropriate support (Starkey, Stevens et al., 2006). Web 2.0 applications can facilitate the interactions across these networked schools.

With schools interacting online, students can develop network connections. Senior students at wharekura and some rural schools access different programmes of learning provided by more than one education provider (Starkey et al., 2006, p. 40). In future students may have their own personalised learning environment (PLE) in which they develop 
knowledge with a range of education providers, and through networks, build their learning programmes according to their needs, interests, goals and aspirations.

\section{Educators networking with educators}

For some teachers the use of web 2.0 has opened access to a wider community of professional support and learning. Connections are made through formal systems such as LeadSpace, ${ }^{4}$ or through networked communities that teachers might opt to join and develop on their own terms, like the edublogger community.

LeadSpace is an existing online environment with information and support for school principals set up by the Ministry of Education. It offers information and web links relevant to principals and provides communication tools such as forums for networking through the site. Facilitators and a helpdesk are available to support principals through LeadSpace. Many of the subject associations have websites for teachers where key information and resources are online. TKI (Te Kete Ipurangi) is a centrally funded resource bank for teachers. Currently most of these sites, government or organisation run, are focused on having information available for teachers and leaders. Few, however, function as knowledge building networks.

The New Zealand Ministry of Education is currently supporting the development of online learning communities (Ministry of Education, 2006, p. 11). These communities will be developed through existing structures such as LeadSpace or TKI

Web 2.0 might have the greatest impact where online communities are developed not through established organizations but through social networking, where people of similar interests connect and interact. This can develop through the use of applications such as blogs (internetbased journals), podcasts (home-made or organisation-made sound recordings available through the internet), forums (written asynchronous discussions) and wikis (web pages developed collaboratively, requiring no technical expertise). In the web 2.0 environment, edubloggers (an international group of self-selected educationalists who use web 2.0 tools) participate at different levels. Some read what others have written and listen to podcasts of discussions, others may have their own blog or wiki, make comments on blog posts or wikis, join in live chats or webcasts, or aggregate the threads of discussions, synthesizing and analyzing the various topics. An example of an edublogging environment is world bridges ${ }^{5}$.
The way that professional learning takes place is changing, as educators build global virtual networks with their peers and other experts to share resources and ideas, problem solve, and develop knowledge. Educators can opt in and out of networks as their time, energy and needs dictate. This evolution in professional learning is worth further examination. At present it is independent of the centralised, regional and school-based models funded by the Ministry of Education.

\section{Students networking with the world}

Through the use of web 2.0 applications, students are able to network to create knowledge within a global environment. Within their class, school and home they can post ideas for their peers, family and teachers to view and give feedback. This can be through a blog, wiki or podcast either individually, in a small group, or as a class. This type of connection and use of digital technology mirrors the way that many teachers currently teach.

Students can use web 2.0 applications to connect with their peers beyond the classroom and beyond their schools. Collaboration between schools nationally or internationally is facilitated as students interact with one another. The Ministry of Education's e-Learning strategy document includes a goal that "students will use ICT to relate to others, work interactively with local and global learning communities and pursue knowledge" (Ministry of Education, 2006, p. 5). The following example illustrates how a class might use web 2.0 tools to network and build knowledge in line with Ministry of Education strategy goal:

A group of year 12 social studies students want to examine an issue about to come before a parliamentary select committee such as whether to legislate for country of origin food labeling. The teacher and students work together to find out about the issue, using the internet to build their knowledge and submission collaboratively. They search through sites which organize and tag websites or URLs such as del.icio.us and technorati to find links and possible networks and to organize their interesting or relevant sites. They develop a blog that records their progress and a wiki to share their findings. The blog and wiki bring in feedback and perspectives from people in USA, Australia, India and Switzerland. They contact and connect with global experts and lobbyists to discuss the issue via an online learning environment such as second life or through skypecasting (free online phone calls that can be recorded and shared as a podcast/webcast) and email. They record their webcast conversations 
and make them available through their wiki. Their knowledge develops collaboratively, connecting beyond the group and will continue to develop and change as they follow (and maybe participate in) the select committee hearings; discussing the results through their blog and wiki, modifying their findings based on feedback and further information. The wiki is developed further by other people online who are interested in this issue.

The pedagogy underpinning this type of learning requires the teacher to be a facilitator of learning with a view of the curriculum as something that is flexible. The outcome of the inquiry is not known by the teacher or students before the study begins. The understandings developed could include participating in a democratic process, global responsibility, critical analysis of food safety regulations and other issues. The students will be digitally literate - they are aware of how to keep themselves safe and aware of possible inaccuracies and bias in the opinions and ideas they might hear. This is part of the critical thinking they would undertake in their education.

The collaboration involved in this type of learning activity includes connections between a group of students, their teacher, experts and interested parties beyond their classroom and beyond their country. They are constructing knowledge through a network that may or may not already exist. This is an example of authentic learning through the use of web 2.0 applications, and illustrates some of the ideas of connectivism (Siemens, 2006).

As students network, connect and interact through the use of web 2.0, their experiences may mediate their transition into the future world of learning beyond school. Skills and understanding that students will need to succeed in this world include: (i) critical thinking - so that they look at information and knowledge creation and make judgments about it; (ii) examining information for bias and underpinning values; (iii) learning how to keep themselves and their identities safe online; (iv) critically analyzing who they interact with online; (v) developing and maintaining learning networks; and (v) developing knowledge within their networks.

Networked students, teachers and schools interacting and building knowledge through digital technologies are likely to function in different ways, requiring teacher education, systems and pedagogies that are aligned with a networked, digital society.

\section{Digital Integration and the Professional Education of Teachers}

Computers have been in schools for thirty years, with minimal impact on the way that students are being taught (Clifford, Friesen \& Lock, 2005; Cuban, 2001). While web 2.0 applications and emerging ideas about knowledge-creation have the potential to change schooling, this is unlikely to happen without a change in the underpinning pedagogical beliefs of teachers.

The technological advances outlined above have implications for the future education of teachers in New Zealand. There are four dimensions that should be included in a teacher education programme that aims to have teachers incorporate collaborative knowledge building through digital technologies in their teaching programmes and professional learning:

\section{(i) Learning theories appropriate for connected learners}

In a report on teacher workloads in New Zealand, researchers found that the effective use of ICT was dependent on a positive learning culture in the school, underpinned by appropriate pedagogy (Ingvarson, Kleinhenz et al., 2005). Pedagogy is the key to effective ICT integration in teaching and learning. Connectivism (Siemens, 2006) is an emerging theory with potential to shape pedagogy in the increasingly digitally integrated system of schools in New Zealand.

\section{(ii) Effective modelling of digital integration in pre-service teaching} placements

Clifford, Friesen \& Lock (2005) noted that "greater modelling ... by partner teachers in the field placements will benefit pre-service teachers." Student teachers who are able to experience effective use of digital technologies while on teaching placement are more likely to become confident users in their own classes. The experience ideally will involve both high school students working collaboratively as part of their classroom learning and teachers working collaboratively with colleagues and experts.

\section{(iii) Experience collaborative learning through web 2.0 to create authentic knowledge}

To gain an understanding of the potential and issues associated with integrating web 2.0 for collaborative knowledge building, teachers should experience learning as their students may experience. Authentic learning should include links beyond the classroom to the wider world 
and/or the world of the learner (Rowan \& Bigum, 2005). This applies to the learner being both the student and the teacher. In a collaborative knowledge building environment, teachers are able to work across schools with their peers around New Zealand and link into or form global learning groups.

\section{(iv) Join professional learning communities through web 2.0}

Building professional learning connections can help establish familiarity and support for ongoing collaborative learning. This can be attained through connecting teachers with common professional interests using web 2.0. Professional learning connections already exist beyond individual schools. The grouping of teaching professionals through professional development clusters, subject associations and ICT networks such as the new digital educational structures outlined above, is likely to continue in the future.

\section{Conclusion}

New Zealand has been integrating digital technologies to encourage collaboration since the 1980s when rural schools connected at a regional level to form digital intranets within which they could share teaching resources. Digital integration in schools is currently reaching a new phase with the introduction of web 2.0, increasing access to broadband connections and changing understanding of the implications of developing a knowledge society.

Teachers integrating web 2.0 will see themselves as facilitators of learning, as guiding hands and as co-learners alongside their students. They will have their own networks for professional learning and will help students to create knowledge through authentic interactions. For many teachers, this requires a pedagogical shift. Teacher education for this phase of digital integration should include learning theories that are appropriate for the digital era. In future, pre-service and practising members of the profession will experience online collaborative knowledge building if they are to be effective in the digitally-integrated environment that students inhabit.

\section{Notes}

1. An earlier version of this paper was presented at the Teacher Education Forum of Aotearoa New Zealand, Dunedin, July 2006.

2. Web2.0 applications enable people to interact through the World Wide Web or other digital technology, forming networks and online communities.
3. <www.virtuallearning.school.nz/>

4. <www.leadspace.govt.nz/>

5. <http://worldbridges.net/>

\section{References}

Bereiter, C. (2002). Education and mind in the knowledge age. Mahwah, NJ: Lawrence Erlbaum.

Bruner, J. (1986). Actual minds, possible worlds. Cambridge, MA: Harvard University Press.

Clifford, P., Friesen, S., \& Lock, J. (2005). Coming to teaching in the 21st century. Study conducted by the Galileo Network. Retrieved 7 November, 2005, from <www.galileo.org/research/publications/ctt.pdf>

Cuban, L. (2001). Oversold and underused: Computers in the classroom Cambridge, MA: Harvard University Press.

Gilbert, J. (2005). Catching the knowledge wave? The knowledge society and the future of education. Wellington: NZCER Press.

Gonzalez, C. (2004). The role of blended learning in the world of technology. Retrieved March 30, 2006, from

<www.unt.edu/benchmarks/archives/2004/september04/eis.htm>

Ingvarson, L., Kleinhenz, E., Beavis, A., Barwick, H., Carthy, I., \& Wilkinson, J. (2005). Secondary teacher workload study report. Wellington: Ministry of Education.

Johnson, M., Kazakov, D., \& Švehla, M. (2005). ICT in schools report 2005. Wellington: 2020 Communications Trust.

Ministry of Education. (2006). Enabling the 21st century learner: An e-learning action plan for schools 2006-2010. Wellington: Learning Media.

Rowan, L., \& Bigum, C. (2005). Transforming frameworks: New approaches to CCTS and the pursuit of educational equity. Paper presented at the British Educational Research Association Conference, Glamorgan, September, 2005. Retrieved March 23, 2006, from $<$ www.deakin.edu.au/education/lit/kps/pubs/RowanBigumBera.rtf>

Siemens, G. (2004). Connectivism: A learning theory for the digital age. Retrieved 15 March, 2006, from

$<$ www.elearnspace.org/Articles/connectivism.htm>

Siemens, G. (2006). Knowing knowledge. Retrieved November 18, 2006, from $<$ http://tc.umanitoba.ca/KnowingKnowledge/index.php/Main_Page > 
Starkey, L., Stevens, S., Taylor, M., Toia, R., Yates, A., Hall, C., McKenzie, L., \& Meyer, L. (2006). School/cluster based secondary qualifications professional development: Review of secondary schools' use of NCEA professional development resources, 2005-2006. Wellington: Ministry of Education.

Stevens, K. J. (1999). Telecommunications technologies, telelearning and the development of virtual classes for rural New Zealanders. Open Praxis 1, 12-14.

Stevens, K. J. (2003). Open learning to sustain rural schools: The replication of a three-stage model. New Zealand Annual Review of Education, 12, 173-186.

Stevens, K. J., \& Moffatt, C. (2003). From distance education to telelearning-The organization of open classes at local, regional and national levels. In J. Bradley (Ed.), The open classroom - distance learning in and out of schools (pp. 171-180). London and Sterling, VA: Kogan.

Vygotsky, L. S. (1987). The history of the development of higher mental functions (M. J. Hall, Trans. Vol. 4). New York: Plenum Press.

\section{The authors}

Louise Starkey is a Lecturer in the Department of Primary and Secondary Teacher Education of the Victoria University of Wellington College of Education. She has a background in secondary education, being a teacher and senior manager in a number of schools in New Zealand. She is interested in the impact of emerging digital technologies and applications on teaching, learning, school structures, student participation and teacher education.

Email: <louise.starkey@vuw.ac.nz>

Ken Stevens is a Professor of Education at Memorial University of Newfoundland, where he was appointed to a chair in e-learning, funded by Industry Canada. His previous appointments were at James Cook University in Queensland, Australia, and at Victoria University of Wellington. In Australia, New Zealand and Canada he has specialized in the provision of education in rural communities and the application of information technologies for teaching and learning in and between schools in sparsely-populated areas. Recently he was cross-appointed as Adjunct Professor of Education at Victoria University of Wellington. He lives in Canada and New Zealand.

Email: <stevensk@mun.ca> 